\title{
SOURCE CHARACTERISTICS OF EARTHQUAKES IN THE MICHOACAN SEISMIC GAP IN MEXICO
}

\author{
By Luciana Astiz, Hiroo Kanamori, and Holly Eissler
}

\begin{abstract}
We investigated the source characteristics of large earthquakes which occurred in the Michoacan, Mexico, seismic gap during the period from 1981 to 1986 in relation to historical seismicity in the region. The rupture pattern of the Michoacan gap during this period can be characterized by a sequential failure of five distinct asperities. Before 1981, the Michoacan gap had not experienced a large earthquake since 1911 when an $M_{s}=7.8$ earthquake occured. The recent sequence started in October 1981 with the Playa Azul earthquake which broke the central part of the gap. Body-wave modeling indicates that the Playa Azul earthquake is $27 \mathrm{~km}$ deep with a seismic moment of $7.2 \times 10^{27}$ dyne-cm. It is slightly deeper than the recent Michoacan earthquakes, and its stress drop is higher, suggesting a higher stress level at depths in the Michoacan gap. The seismic moment of the 19 September $1985\left(M_{w}=8.1\right)$ earthquake was released in two distinct events, with the rupture starting in the northern portion of the seismic gap and propagating to the southeast with low moment release through the area already broken by the 1981 Playa Azul earthquake. The rupture propagated further southeast with an $\boldsymbol{M}_{\boldsymbol{w}}=7.5$ event on 21 September 1985. Another aftershock occurred on 30 April 1986 to the northwest of the 19 September main shock. Body-wave modeling indicates that this event has a simple source $10 \mathrm{sec}$ long at $21 \mathrm{~km}$ depth, and fault parameters consistent with subduction of the Cocos plate $\left(\theta=280^{\circ}, \delta=12^{\circ}\right.$, and $\left.\lambda=70^{\circ}\right)$ and $M_{0}=2.0$ to $3.1 \times 10^{26}$ dyne-cm $\left(M_{w}=6.8\right.$ to 6.9). Although this distribution of asperities is considered characteristic of the Michoacan gap, whether the temporal sequence exhibited by the 1981 to $\mathbf{1 9 8 6}$ sequence is also characteristic of this gap or not is unclear. It is probable that, depending on the state of stress in each asperity, the entire gap may fail in either a single large event with a complex time history or a sequence of moderate to large events spread over a few years. The seismic moment and the time since the last earthquake in Michoacan (in 1911) fit an empirical relation between moment and recurrence time found for the Guerrero-Oaxaca region of the Mexico subduction zone.
\end{abstract}

\section{INTRODUCTION}

The 19 September 1985, Michoacan, Mexico, earthquake $\left(M_{S}=8.1\right.$, hereafter referred to as the 1985 Michoacan earthquake) is the most serious natural disaster to date in Mexico's history; it caused over 10,000 deaths in Mexico City and left an estimated 250,000 homeless. This earthquake occurred along a segment of the Cocos-North American plate boundary that had been identified as the Michoacan seismic gap (Kelleher et al., 1973). A series of large earthquakes have occurred in this gap (Table 1). They include the 1981 Playa Azul earthquake $\left(M_{S}=M_{W}=7.3\right)$, and two large aftershocks which occurred on 21 September $1985\left(M_{S}=M_{W}=7.5\right)$ and 30 April $1986\left(M_{S}=7.0\right)$.

In order to understand the overall rupture pattern of this gap, we investigated the source characteristics of the major events which occurred in this gap. This paper summarizes the results and complements our preliminary investigation on the main event of the 1985 Michoacan earthquake (Eissler et al., 1986). In addition, we provide a summary of results by other investigators and a discussion of historical seismicity in this region. 
TABLE 1

Source Parameters of Earthquakes in the Michoacan Gap

\begin{tabular}{|c|c|c|c|c|c|c|c|c|c|c|c|c|}
\hline \multirow{2}{*}{ Date } & \multirow{2}{*}{ Hr:Mn:Sec } & \multicolumn{2}{|c|}{ Location } & \multirow{2}{*}{$\begin{array}{l}\text { Depth } \\
(\mathrm{km})\end{array}$} & \multirow{2}{*}{$M_{S}$} & \multirow{2}{*}{$M_{w}$} & \multirow{2}{*}{$\underset{\left(\times 10^{27} \mathrm{~d}\right.}{M_{o b^{\dagger}}}$} & \multirow{2}{*}{$\begin{array}{c}M_{\text {os }} \ddagger \\
\text { lyne-cm) }\end{array}$} & \multicolumn{3}{|c|}{$\begin{array}{c}\text { Fault } \\
\text { Parameters }\end{array}$} & \multirow{2}{*}{ Reference§ } \\
\hline & & $\begin{array}{c}\text { Latitude } \\
\left({ }^{\circ} \mathrm{N}\right)\end{array}$ & $\begin{array}{c}\text { Longitude } \\
\left({ }^{\circ} \mathrm{W}\right)\end{array}$ & & & & & & $\theta$ & $\delta$ & $\lambda$ & \\
\hline \multirow[t]{3}{*}{7 June 1911} & 11:02:35 & 17.5 & 102.5 & $S$ & 7.8 & & & & & & & 1 \\
\hline & $10: 26: 48$ & 19.7 & 103.7 & 100 & 8.0 & & & & & & & 2 \\
\hline & & 19.7 & 103.7 & $S$ & 7.9 & & & & & & & 3 \\
\hline \multirow[t]{5}{*}{25 October 1981} & $03: 22: 15$ & 18.048 & 102.084 & $33^{*}$ & 7.3 & & & & & & & 4 \\
\hline & $03: 22: 13$ & 17.75 & 102.25 & $20^{*}$ & & & & & 290 & 11 & 90 & 5 \\
\hline & & & & & & 7.3 & & 1.3 & 278 & 12 & 67 & 6 \\
\hline & 03:22:34 & 18.28 & 102.00 & 31.8 & & 7.2 & & 0.7 & 287 & 20 & 82 & 7 \\
\hline & & & & 27 & & 7.2 & 0.72 & & 285 & 11 & 75 & 8 \\
\hline \multirow[t]{4}{*}{19 September 1985} & $13: 17: 48$ & 18.190 & 102.533 & 27.9 & 8.1 & & & & & & & 4 \\
\hline & & 18.141 & 102.707 & $16^{*}$ & & & & & & & & 9 \\
\hline & $13: 18: 24$ & 17.91 & 101.99 & 21.3 & & 8.1 & & 11.0 & 301 & 18 & 105 & 7 \\
\hline & & & & 17 & & 8.05 & 7.2 & 10.5 & 288 & 9 & 72 & 10 \\
\hline \multirow[t]{4}{*}{21 September 1985} & $01: 37: 13$ & 17.802 & 101.647 & 30.8 & 7.6 & & & & & & & 4 \\
\hline & & 17.618 & 101.815 & $16^{*}$ & & & & & & & & 9 \\
\hline & $01: 37: 32$ & 17.57 & 101.42 & 20.8 & & & & 2.5 & 296 & 17 & 85 & 7 \\
\hline & & & & 22 & & 7.6 & 1.2 & 2.9 & 288 & 9 & 72 & 8 \\
\hline \multirow[t]{2}{*}{30 Apr 1986} & 07:07:19 & 18.404 & 102.973 & 26.5 & 7.0 & & & & & & & 4 \\
\hline & 07:07:30 & 18.25 & 102.92 & 20.7 & & 6.9 & & 0.3 & 290 & 18 & 87 & 7 \\
\hline
\end{tabular}

* Fixed depth.

$\dagger M_{o b}=$ seismic moment from body waves.

$\ddagger M_{o s}=$ seismic moment from surface waves.

$\S 1=$ Gutenberg and Richter (1954); $2=$ Figueroa, (1970); $3=$ Singh et al. $(1980) ; 4=$ NEIC; $5=$ Havskov et al. (1983); $6=$ LeFevre and McNally (1985), values from moment tensor inversion; $7=$ centroid moment tensor inversion from Harvard published by NEIC; $8=$ this study; $9=$ UNAM Seismology Group (1986); 10 = Eissler et al. (1986).

\section{Previous Large Subduction Earthquakes in Middle America}

The Middle America trench has been the site of numerous large thrust earthquakes that rupture discrete segments 100 to $200 \mathrm{~km}$ long. An average recurrence interval for the plate boundary of $33 \pm 8 \mathrm{yr}$ was found by McNally and Minster (1981), although different subsegments have somewhat different recurrence intervals (Singh et al., 1981; Astiz and Kanamori, 1984). Figure 1 shows the aftershock areas of all large $(M \geqq 7)$ shallow thrust events that occurred off coastal Mexico since 1950 (updated from Eissler et al., 1986). The 1957 Acapulco earthquake ( $M_{S}$ $=7.5$ ) which occurred in southern Guerrero caused damage in Mexico City, but the number of structures experiencing complete collapse was far less than for the 1985 Michoacan earthquake. The dashed region shown in Figure 1 is the aftershock zone of the 1932 Jalisco earthquake $\left(M_{S}=8.1\right)$, the largest earthquake in Mexico prior to 1985 (Singh et al., 1985). This event ruptured the interplate boundary between the Rivera and North American plates and has a longer recurrence interval.

Figure 2 is a time-distance plot of large earthquakes along the Middle America trench from 1800 to 1985 (updated from Astiz and Kanamori, 1984). Location accuracy varies with time; however, it is evident that large earthquakes have occurred along most of this plate boundary in the last hundred years. Hatched segments indicate seismic gaps, and dotted regions (nos. 3, 11, and 19) indicate the segments where seafloor high topographic features are being subducted. Note that most of the Central America coast has not experienced a major thrust earthquake 


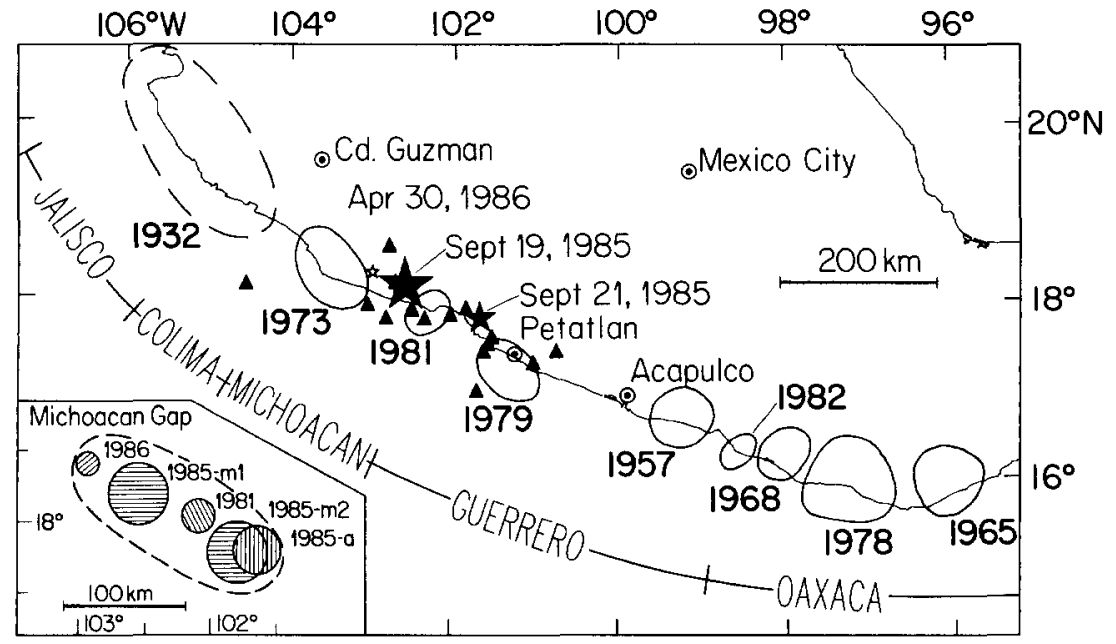

FIG. 1. Map of central Mexico showing the aftershock areas (ellipses) of interplate thrust events since 1950 with $M>7$. The September 1985 Michoacan earthquake is plotted as a filled star, and its $M_{S}$ $=7.5$ aftershock as a smaller star. The epicenter of the $M_{S}=7.0$ aftershock of 30 April 1986 is shown as an open star. Other plotted symbols are preliminary locations of the 1-month aftershocks from the National Earthquake Information Center. The dashed region is the aftershock area of the $M_{S}=8.11932$ Jalisco earthquake. The lower left corner shows schematically the rupture pattern of the Michoacan gap outlined by a dashed curve. The circles represent location of asperities on the fault plane. The radius of the cirlce is proportional to $M_{0}{ }^{1 / 3}$.

during the last $30 \mathrm{yr}$ (regions 14 to 16 ). In the Mexican subduction zone, north of Tehuantepec, major gaps are observed in Jalisco (region 1) and Guerrero (region 5).

The Guerrero gap can be seen in Figure 1 south of the 1979 Petatlan rupture zone. The last major events located here around the turn of the century: 1899; 1907; and 1909. The surface-wave magnitude of the 1899 event is estimated at 7.5 to 7.9 and that of the 1909 event at 7.4 (Abe, 1973; Singh et al., 1981). The 1907 earthquake has an estimated moment magnitude $\left(M_{W}\right)$ of 7.8 , and on the basis of detailed intensity data appears to have broken the region involved in the 1957 Acapulco earthquake. Since the distance from Mexico City to the Guerrero gap is shorter than to any other region along the Middle America trench, damage to Mexico City may be severe from future earthquakes in the Guerrero region. An accelerograph network to study the expected activity in the Guerrero gap was placed in the coastal regions of Guerrero and Michoacan in mid-1985 and recorded near-field data from the 1985 Michoacan earthquake (Anderson et al., 1986).

Since the establishment of the World Wide Standardized Seismograph Network (WWSSN), numerous large earthquakes have occurred in the Middle America trench. Figure 3 shows long-period body waves recorded at the Eskdalemuir, Scotland, station for all large $\left(M_{S} \geqq 7\right)$ events that occurred in this region from 1965 to 1986 . We can compare the waveforms since all earthquakes are at approximately the same distance and azimuth from Eskdalemuir, $80^{\circ}$ and $35^{\circ}$, respectively. Most events are relatively simple, but the 1985 Michoacan earthquake is more complex and has the largest peak-to-peak amplitude (the $P$ wave was nearly offscale). Detailed studies of the source parameters of these events indicate that most recent large earthquakes along Middle America show remarkably simple fault processes for long (>10 sec) periods (e.g., Reyes et al., 1979; Stewart et al., 1981; Chael and Stewart, 1982; LeFevre and McNally, 1985; Astiz and Kanamori, 1984). At short periods, their sources are more complex (Tajima, 1984). The focal mechanisms of these events indicate thrusting consistent with the subduction of the Cocos 


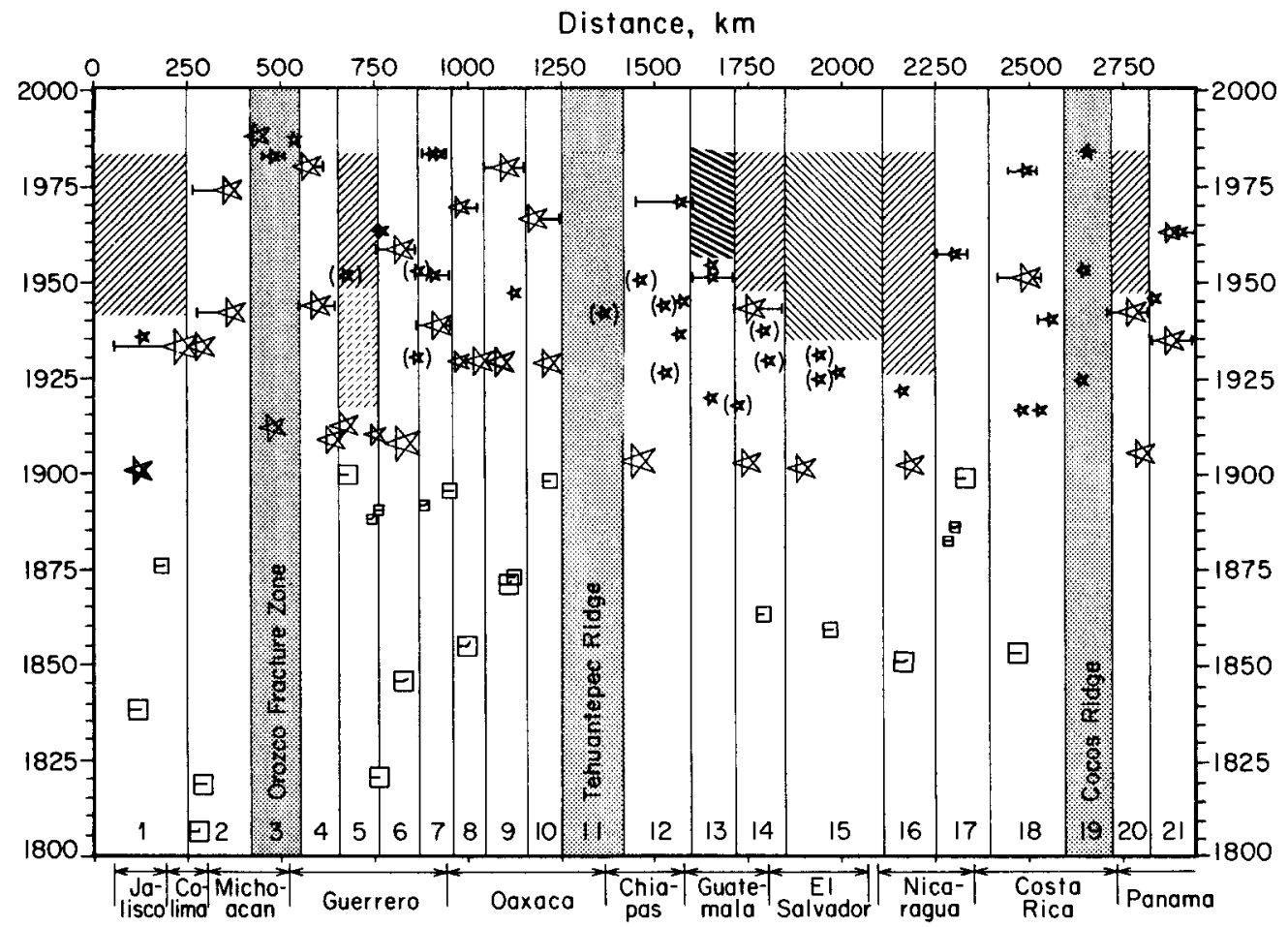

FIG. 2. Time-distance plot of large earthquakes $(M>7)$ along the Middle America trench. Stars are large events that occurred during this century. Squares indicate last century events. Bars indicate the extent of known aftershock zones. Names at the bottom refer to Mexican coastal states and Central American countries. Numbers at the bottom refer to regions determined from aftershock distribution of recent earthquakes. Dotted regions correspond to the projection of seafloor topographic highes. Hatched sections indicate seismic gaps: Jalisco (1); Guerrero (5); Guatemala (14); El Salvador (15); Nicaragua (16); and West Panama (20). Notice that the former Michoacan gap (3) was ruptured during the September 1985 earthquakes (modified from Astiz and Kanamori, 1984).

plate to the northeast and with the gently dipping Benioff zone. European recordings of large Mexican earthquakes that occurred from 1907 to 1962 indicate that these events share the same characteristics of the more recent well-studied events: they are shallow thrust events (generally at about $16 \mathrm{~km}$ depth) with a relatively simple source with the possible exception of multiple-source earthquakes on 7 June 1911 in Michoacan, 3 and 18 June 1932 in Jalisco, and on 22 February 1943 near Petatlan (Singh et al., 1984; see also Figure 4 of the UNAM Seismology Group, 1986).

\section{The Michoacan Gap and the SePtember 1985 Earthquake}

The area between the 1973 Colima and the 1957 Acapulco earthquake had been designated a seismic gap in several studies of global earthquake activity (Figure 1; Kelleher et al., 1973; McCann et al., 1979). Depending on consideration of a large earthquake in 1943 in the center of this segment, the area was either discussed as a single gap of large dimensions $(\approx 400 \mathrm{~km})$ or as two separate gaps to the north and south of the 1943 event. In 1979, the Petatlan earthquake occurred in the center of the segment at the same location as the 1943 event, clearly separating the region into two quiescent zones designated the Michoacan and the Guerrero gaps, each approximately $150 \mathrm{~km}$ long (Singh et al., 1981).

The last large earthquake $\left(M_{S}=7.9\right)$ in the Michoacan gap was in 1911; its location had been determined by Gutenberg and Richter (1954). On the basis of 


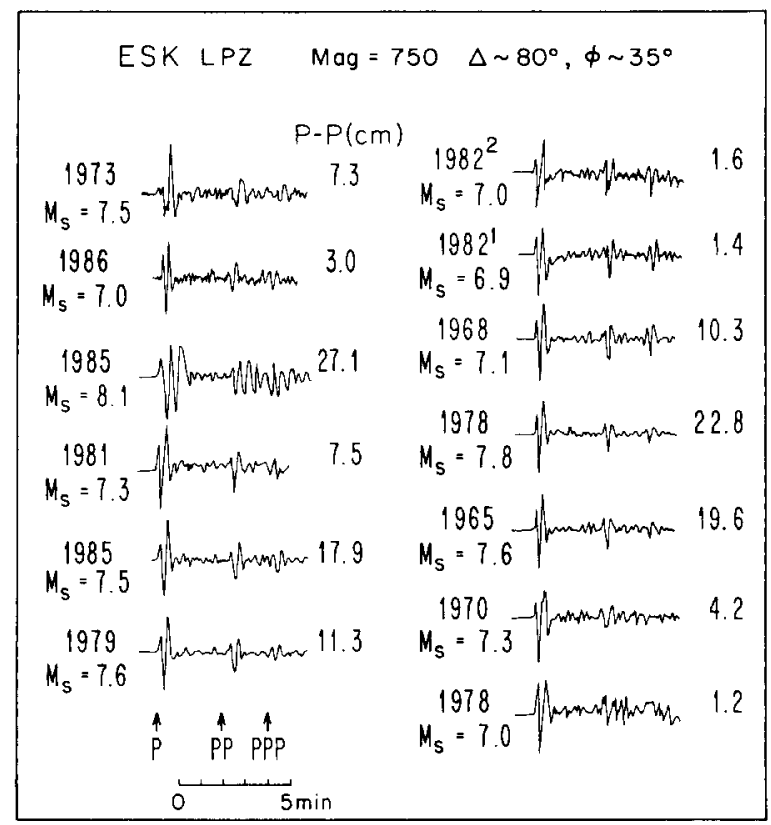

FIG. 3. Vertical long-period WWSSN seismograms of $P, P P$, and $P P P$ waves recorded at Eskdalemuir, Scotland $(\mathrm{ESK})$ are shown for large shallow $\left(M_{S}>7\right)$ subduction events which occurred along the Middle America trench between 1965 and 1986. The events are ordered from northwest to southeast along the trench. Peak-to-peak $(P-P)$ amplitudes in centimeters are indicated for each record. $P$ waves of the great 1985 Michoacan earthquake are on scale at this station due to its low magnification (magnitude $=750$ ). Note the relatively simple waveforms for most events. However, a more complex source is clearly seen for the 1985 Michoacan earthquake which also displays the largest peak-to-peak amplitude.

damage reports of the 1911 earthquake and the relocation of an aftershock, Singh et al. (1980) suggested that the event was not located offshore Michoacan but about $200 \mathrm{~km}$ farther northwest in Jalisco. This suggestion and the lack of other large Michoacan earthquakes in the historic record (see Figure 2) led several researchers to consider that the Michoacan area might be a "permanent" seismic gap due to the influence of the Orozco fracture zone (Singh et al., 1980; McNally and Minster, 1981). Locally, the frature zone is a broad area of disturbed seafloor that intersects the Middle America trench for about $150 \mathrm{~km}$ in the Michoacan area. One possible explanation of the lack of large earthquakes in Michoacan was that the Orozco fracture zone was locally affecting the subduction process such that the area was subducting aseismically, or at least more slowly than adjacent regions of the plate boundary. In southern Oaxaca where the Tehuantepec Ridge is subducting, there are likewise no known large $(M>7)$ earthquakes in the historic record since at least 1800 (Figure 2, region 11). Alterations of subduction characteristics such as local decrease in seismicity, a local change in the dip and depth extent of the Benioff zone, and a local change in the stress axes of earthquakes have been observed in many other circum-Pacific regions where ridges, fracture zones, and other areas of topographically anomalous seafloor are subducting (Kelleher and McCann, 1976; Vogt et al., 1976). The occurrence of the great earthquake in Michoacan in 1985 suggests that the seismic potential of areas similar to the previous Michoacan gap, such as southernmost Oaxaca near the Tehuantepec Ridge, should be carefully examined.

In 1981, the Playa Azul earthquake $\left(M_{W}=7.3\right)$ occurred in the center of the 
Michoacan gap (Figure 1). This event was widely felt in southern Mexico, causing damage in the state of Michoacan and in Mexico City where 11 people were injured and one person died. Its aftershock area, seismic moment, and inferred slip indicated that the event was not large enough to fill the gap (Havskov et al., 1983; LeFevre and McNally, 1985).

The epicenter of the 1985 Michoacan earthquake was located in the northern segment of the Michoacan gap beween the 1973 and the 1981 aftershock zones, as shown by the large star in Figure 1. The largest aftershock $\left(M_{S}=7.5\right)$ occurred approximately $36 \mathrm{hr}$ after the main shock, on 21 September (small filled star), in the southern portion of the gap between the 1981 and 1979 aftershock zones. After several months of decreasing seismic activity in the Michoacan region, a large aftershock $\left(M_{S}=7.0\right)$ occurred on 30 April 1986. This event (open star in Figure 1) was located about $50 \mathrm{~km}$ northwest of the main shock epicenter. These large aftershocks from the Michoacan earthquake were felt in the Mexico City area as well as in Ciudad Guzman and Guadalajara in the state of Jalisco.

\section{The Location of THE 1911 Earthquake}

In light of the 1985 Michoacan earthquake, we reconsidered the location of the 1911 event, placed offshore Michoacan by Gutenberg and Richter (1954) and in Jalisco by Singh et al. (1980). The literature indicates that the intensity pattern of the 1911 event is similar to the 1985 earthquake, suggesting a similar epicenter near coastal Michoacan. For example, the "center of disturbance" in terms of deaths, damage to homes, and strong shaking from the 1911 event was placed near Ciudad Guzman in Jalisco (Branner, 1912; Figueroa, 1959). This town was also severely impacted by the 1985 Michoacan earthquake in terms of damaged homes and deaths. Further, the 1911 event caused fatalities in Mexico City and had the highest intensity (VIII) in the city of any earthquake during the reporting period of 1900 to 1959 (Figueroa, 1959). Thus, the 1911 event may have been felt as strongly in Mexico City as the 1985 earthquake, but was less damaging there because of the smaller population and smaller degree of urban development in 1911 . We reexamined the supporting material for Gutenberg's epicenter determination (Goodstein et $a l ., 1980$ ) and found that time difference between $S$ and $P$ waves from three stations in Mexico (Mazatlan, Oaxaca, and Merida) and one direct $P$ time from Tacubaya (Mexico City) were included among the 20 arrival times used to determine their epicenter. The conclusion of Singh et al. (1980) that the event actually occurred in Jalisco was strongly based on the earthquake's destructive effects in Ciudad Guzman. Considering the similarity of the intensity patterns of the 1911 and 1985 events, and the fact that arrival times from nearby stations had been used in the original location, we take the Michoacan location of Gutenberg and Richter (1954) as the more likely epicenter for the 1911 earthquake. This epicenter is at $17.5^{\circ} \mathrm{N}$, $102.5^{\circ} \mathrm{W}, 87 \mathrm{~km}$ south of the 1985 Michoacan earthquake. With the 1911 event, the estimate of the recurrence period of large subduction earthquakes in the Michoacan area is $74 \mathrm{yr}$. Astiz and Kanamori (1984) determined observed recurrence periods for the Colima and Petatlan segments adjacent to the Michoacan segment at 21.3 \pm 10.5 and $35.5 \pm 0.7 \mathrm{yr}$, respectively.

\section{Source Parameters from Body-Wave Modeling}

Forward modeling of teleseismic $P$ waves over a wide azimuthal range was done to determine the focal mechanism, point source depth, and source-time function of the 1985 Michoacan earthquake, the $M_{S} 7.5$ and 7.0 aftershocks, and the Playa Azul 
earthquake. We use the simple geometric ray approach described in Langston and Helmberger (1975) and Kanamori and Stewart (1976). Three rays $(P, p P$, and $s P)$ were used, and half-space velocities of $V_{P}=6.2 \mathrm{~km} / \mathrm{sec}$ and $V_{S}=3.5 \mathrm{~km} / \mathrm{sec}$ with a density of $\rho=2.6 \mathrm{gm} / \mathrm{cm}^{3}$ were assumed for all the events.

The 19 September 1985 earthquake. First-motion data are plotted in Figure 4 and listed in Table 2 . The first-motion data constrain one steeply dipping nodal plane with $\operatorname{dip} \delta=81^{\circ}$ and strike $\theta=127^{\circ}$, and the orientation of the second plane was resolved with waveform modeling. Figure 4 shows observed $P$-wave seismograms from 12 WWSSN stations and one GEOSCOPE station (SSB) and synthetic seismograms calculated for the focal mechanism, point source depth, and time function that provided optimal waveform fit for the main shock. The time function is a multiple source consisting of two trapezoids of equal duration (16 sec) and seismic moment, and the second source beginning $26 \mathrm{sec}$ after the first (on the average). The point source depth is $17 \mathrm{~km}$, and the focal mechanism shows an overall thrust geometry on a low angle plane $\left(\delta=9^{\circ}, \theta=288^{\circ}\right.$, and $\left.\lambda=72^{\circ}\right)$. The horizontal projection of the slip vector orientation is $\mathrm{N} 39^{\circ} \mathrm{E}$, which agrees with the local convergence direction of the Cocos plate calculated at the epicenter from the RM2 pole of rotation (Minster and Jordan, 1978). The seismic moment estimated from the $P$-wave amplitudes is $7.2 \pm 1.6 \times 10^{27}$ dyne-cm. Many of the $P$ waves were diffracted arrivals $\left(\Delta>100^{\circ}\right)$, and these were not used in the estimate of seismic moment.

It was necessary to adjust the time separation, $t_{0}$, between the two sources as a function of azimuth to obtain the best waveform fit. The time separations range from a minimum of $21 \mathrm{sec}$ for South American stations in southeast azimuths to a maximum of $31 \mathrm{sec}$ for Japanese and mid-Pacific stations in northwest azimuths (Figure 5). European stations (northeast azimuths), South Pacific and Australian stations (southwest azimuths), and Antarctica (to the south) have intermediate time separations of 26,28 , and $24 \mathrm{sec}$, respectively. This systematic variation

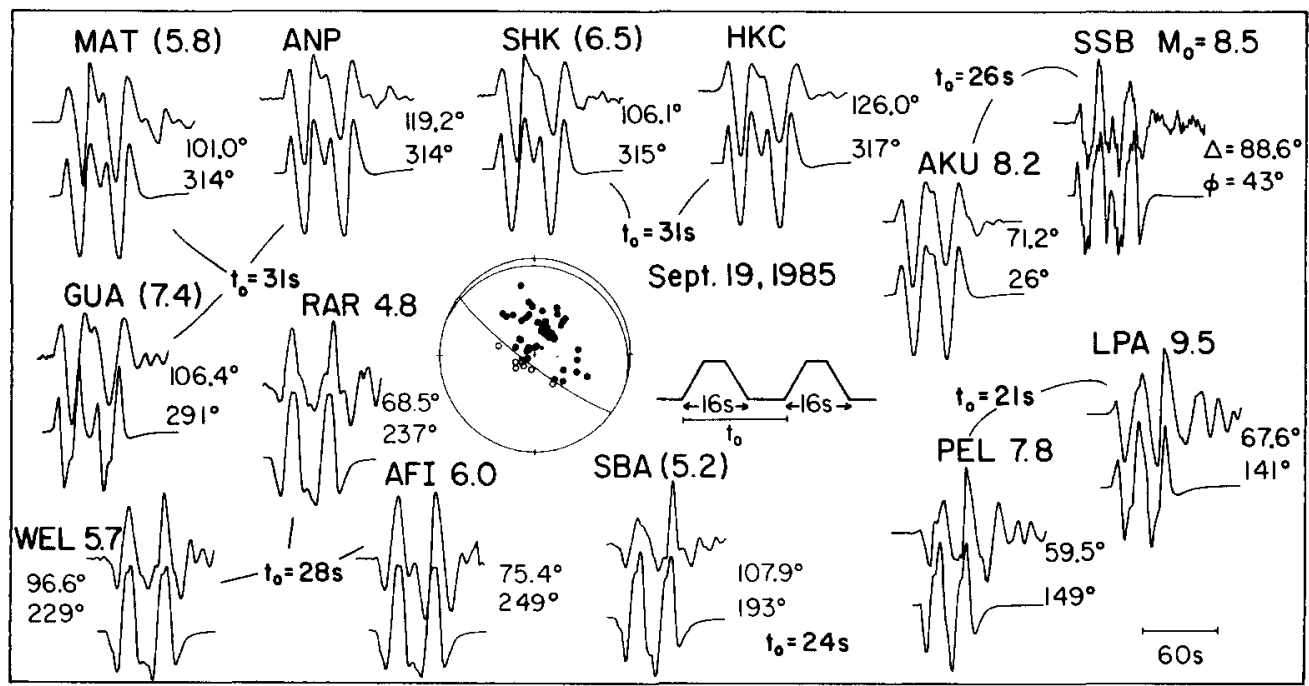

Fig. 4. $P$ waves of the 19 September Michoacan earthquake at teleseismic distances. Observed and calculated waveforms shown are from long-period WWSSN recordings and one GEOSCOPE station (SSB). The synthetic seismograms are for a shallow thrust fault subparallel to the Mexican trench $(\phi=$ $288^{\circ}, \delta=9^{\circ}$, and $\lambda=72^{\circ}$ ) with a point source depth of $17 \mathrm{~km}$ and a two source-time function whose time separation, $t_{0}$, varies systematically with azimuth, indicating source directivity. The value next to the station code is the amplitude ratio of observed to synthetic seismogram from which the average seismic moment is $M_{0}=7.2 \times 10^{27}$ dyne-cm. Values in parentheses are not considered in determining this value. 
TABLE 2

$P$-Wave Data From WWSSN Stations for the 19 SEPTEMBER EVENT

\begin{tabular}{|c|c|c|c|c|c|c|c|}
\hline $\begin{array}{c}\text { Station } \\
\text { Code }\end{array}$ & Station Name & $\begin{array}{c}\text { Distance } \\
\left({ }^{\circ}\right)\end{array}$ & $\begin{array}{c}\text { Azimuth } \\
\left({ }^{\circ}\right)\end{array}$ & $P^{*}$ & $\begin{array}{l}A_{P_{1}}^{\dagger} \\
(\mathrm{cm})\end{array}$ & $\begin{array}{l}A_{P 2} \ddagger \\
(\mathrm{cm}) \\
\end{array}$ & $\begin{array}{c}t_{0} 8 \\
(\mathrm{sec})\end{array}$ \\
\hline AKU & Akureyri, & 71.2 & 25.8 & $\mathrm{C}$ & 30.2 & 23.5 & 26 \\
\hline & & & & $\mathrm{C}$ & & & \\
\hline LPA & La Pla & 67.6 & 11.5 & D & 6.7 & 9.8 & 21 \\
\hline PEL & Pelde & & & D & 4.1 & 7.1 & 21 \\
\hline SBA & & & & D & 1.2 & 2.1 & \\
\hline WE & & & & D & 3.7 & 4.8 & \\
\hline RAR & Rar & & 7.6 & D & 7.2 & 9.2 & \\
\hline ADE & Adel & 123.5 & 39.8 & D & 0.5 & 0.6 & \\
\hline AF & & & & D & 4.8 & 6.4 & 28 \\
\hline & & & & D & 0.9 & 0.7 & 29 \\
\hline & & & & $\mathrm{C}$ & 2.2 & & 31 \\
\hline $\mathrm{D}$ & & & & $\mathrm{C}$ & & .8 & \\
\hline BAG & & 5.4 & 306.5 & $\mathrm{C}$ & 1.1 & 1.0 & - \\
\hline ANP & & & 313.9 & $\mathrm{C}$ & 1.8 & 1.3 & 31 \\
\hline MAT & Mats & 101.0 & 314.3 & C & 4.8 & 4.0 & 31 \\
\hline SHK & Shimal: Inm & & & $\mathrm{C}$ & 3.9 & 2.7 & 31 \\
\hline $\mathrm{HKC}$ & Hong Kong, China & 126.0 & 316.9 & & 0.7 & 0.6 & 31 \\
\hline
\end{tabular}

${ }^{*} P=$ polarity of the $P$ wave; $\mathrm{C}=$ compression; $\mathrm{D}=$ dilatation.

$\dagger A_{P 1}=$ peak-to-peak amplitude at magnification $=750$ of the first $P$-wave pulse.

$\ddagger A_{P 2}=$ peak-to-peak amplitude at magnification $=750$ of the second

$P$-wave pulse.

$\S t_{0}=$ time delay between the first and second sources.

indicates that the second source occurred to the southeast of the first. The actual time separation, $\tau$, at the source and spatial separation, $L$, of the subevents can be estimated from the azimuthal variation of $t_{0}$, which is given by

$$
t_{0_{i}}=\tau-\frac{L}{c_{i}} \cos \phi_{i} .
$$

Here, $c_{i}$ is the $P$-wave phase velocity for the $i$ th station and $\phi_{i}=\phi_{r}-\phi_{S i}$, where $\phi_{S i}$ is the azimuth to the station and $\phi_{r}$ is the rupture direction. Using (1), the data listed in Table 2, and assuming $\phi_{r}=120 \pm 5^{\circ}$, which is the local strike of the trench, we obtained $\tau=26 \mathrm{sec}$ and $L=95 \mathrm{~km}$.

The multiple-source and southeast rupture directions have been noted by many studies regarding the source of the Michoacan earthquake. Two subevents or distinct durations of energy release were observed in strong motion accelerograms near the epicenter (Anderson et al., 1986). These records suggest that the second source occurred approximately $95 \mathrm{~km}$ southeast of the first (UNAM Seismology Group, 1986). Houston and Kanamori (1986) obtained a source-time function similar to our result using teleseismic broadband records from the Global Digital Seismic Network (GDSN). From the directivity, they estimated that the second source began $26 \mathrm{sec}$ after and $82 \pm 7 \mathrm{~km}$ east-southeast of the first at azimuth of $114^{\circ}$. Using a similar broadband GDSN data set, Ekstrom and Dziewonski (1986) determined that the second source began $28 \mathrm{sec}$ after and approximately $70 \mathrm{~km}$ eastsoutheast of the first at azimuth $97^{\circ}$. Priestley and Masters (1986) estimated a time separation of $25 \mathrm{sec}$ with the second source located $70 \mathrm{~km}$ southeast of the first. These results are all consistent with the picture that the rupture began in the 


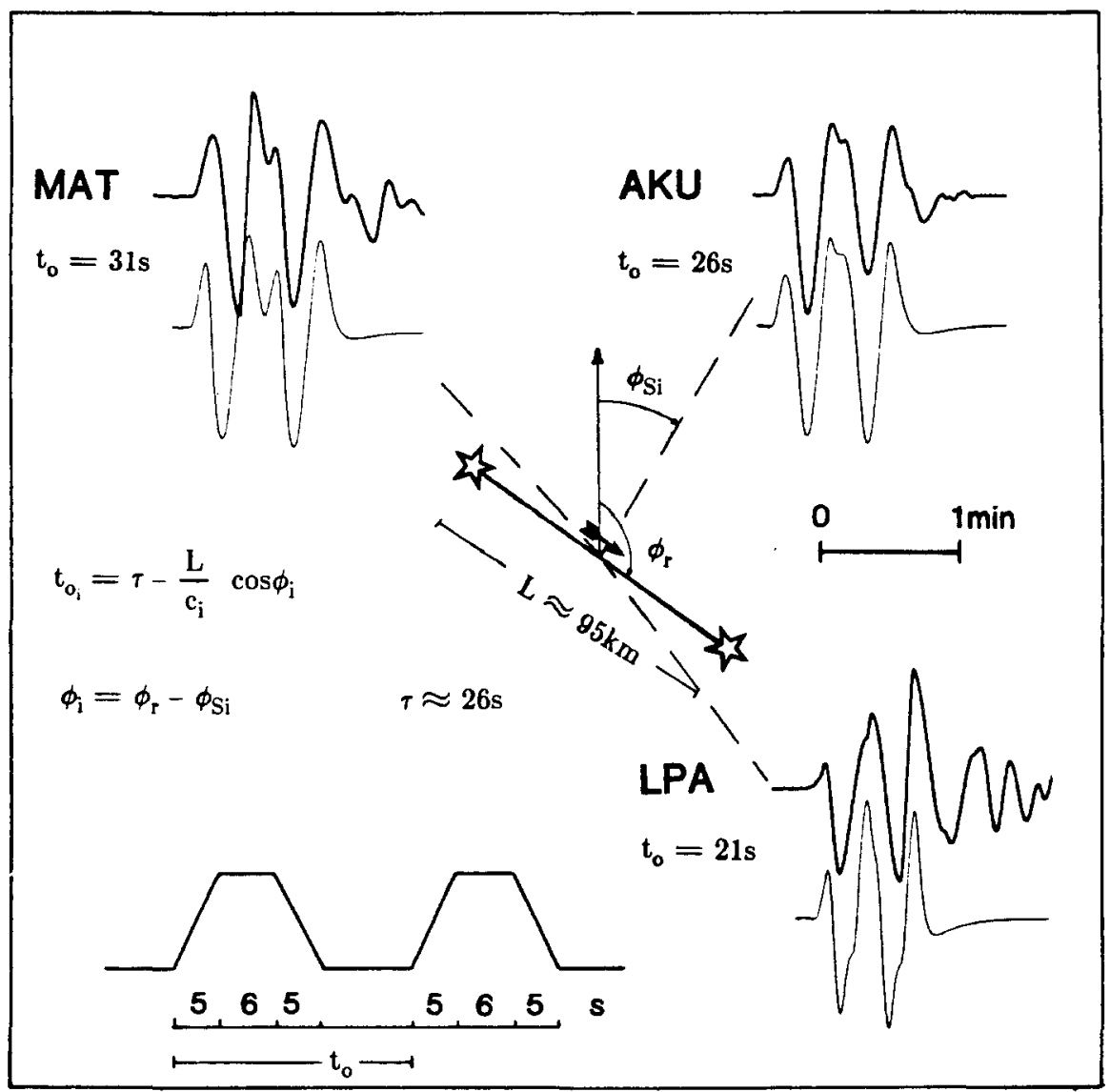

FIG. 5. Observed and synthetic $P$-wave traces from three selected long-period WWSSN stations. The time separation, $t_{0}$, between the trapezoidal source-time functions decreases from northwest to southeast, indicating directivity. From the azimuthal variation of $t_{0}$, the spatial and temporal separation between the two sources (stars) and the rupture direction (arrow) can be estimated.

northern portion of the Michoacan gap (first source), propagated with low moment release through the rupture area of the 1981 Playa Azul earthquake, and then broke the remaining asperity in the southern segment of the gap (second source). The source depth and focal mechanism of the Michoacan earthquake are essentially the same as those of all other large Mexico interplate subduction events studied to date, but the double source-time function is unusual. Most of the large Mexico subduction events have very simple time functions (Chael and Stewart, 1982), and for the few events that show a complex time function, the dominant moment release still occurs in one simple pulse (Astiz and Kanamori, 1984; Singh et al., 1984). The exception is the 1932 Jalisco earthquake, which had a second event of equal size approximately $30 \mathrm{sec}$ after the first and a total seismic moment of about $1.0 \times 10^{28}$ dyne-cm, similar to the source of the Michoacan earthquake (Wang et al., 1982; Singh et al., 1984). Earthquakes with larger seismic moments, such as those in 1932 and 1985, in general have larger rupture zones, so that if the asperity distribution of the Mexico subduction zone is fairly homogeneous with moderate-sized asperities, a large $(M>8)$ earthquake will likely break through several asperities to create a multiple-source time function.

The complexity of the 1985 Michoacan earthquake is reflected in the radiation of short-period waves. Figure 6 shows seismograms of the earthquakes from the 


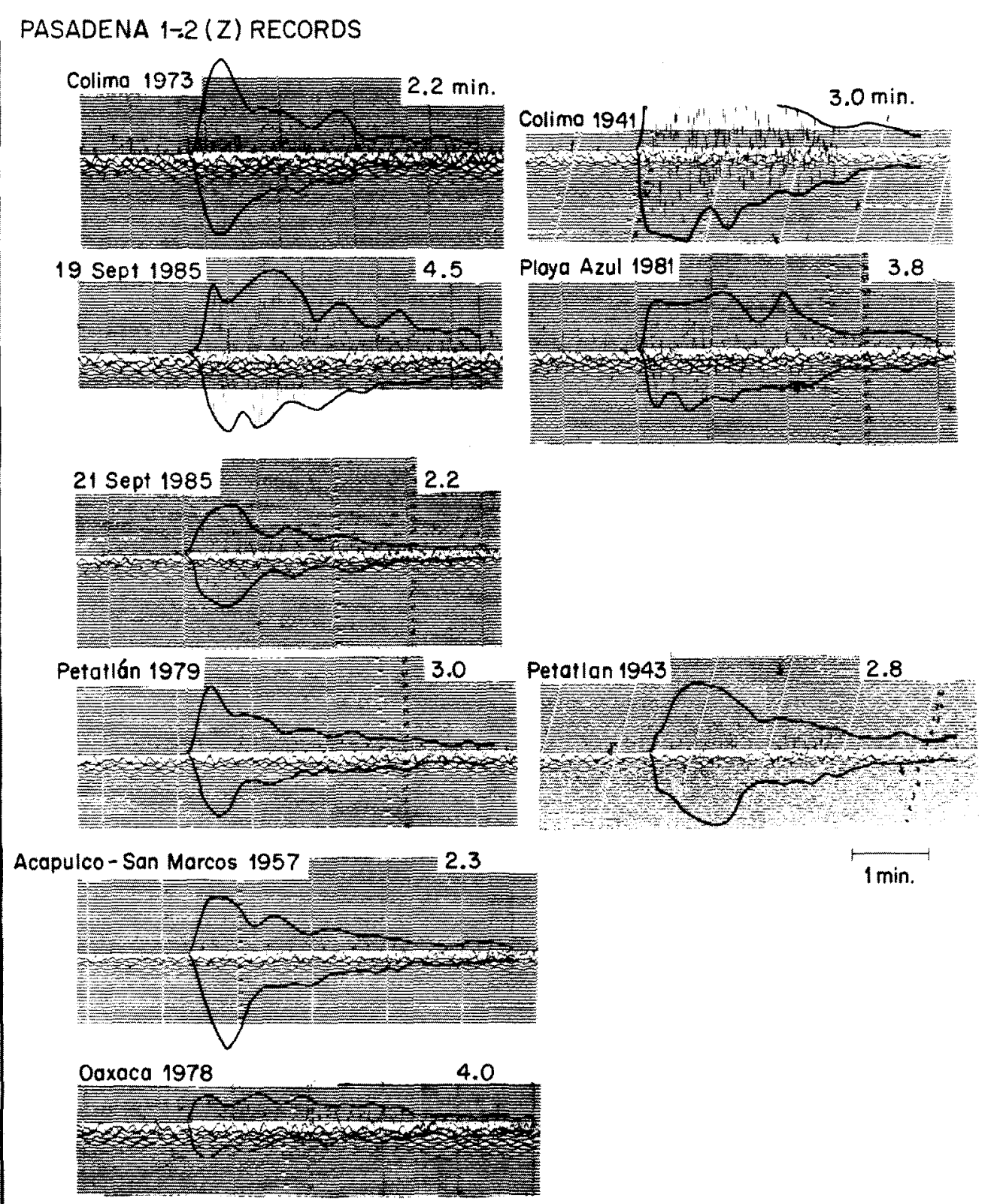

FIG. 6. Vertical short-period Benioff $\left(T_{0}=1 \mathrm{sec}, T_{g}=0.2 \mathrm{sec}\right)$ records at Pasadena for the large interplate thrust events in Mexico. Events are ordered geographically from northwest (top) to southeast (bottom). Continuous lines show the amplitude envelopes for each trace. Note that large amplitudes have a longer duration for the 19 September 1985 earthquake. Indicated values are coda length of $P$ waves in minutes.

short-period vertical Benioff instrument at Pasadena. The dark lines indicate the amplitude envelopes of the records. Most of the events have similar envelope shapes (e.g., 1973, 1979, 1957, and 21 September 1985), but the 19 September Michoacan event clearly maintains larger amplitudes for a longer period of time and has a different envelope shape, indicating a longer source duration or multiple-time function. The numbers in Figure 6 give a measure of coda duration; they are the time in minutes for the amplitude to fall off to one-fourth its maximum, where the 
time is measured from the beginning of the signal. The 19 September Michoacan earthquake has the longest coda duration at $4.5 \mathrm{~min}$; the Colima 1941, Playa Azul 1981, and Oaxaca 1978 also have large coda durations. This unusually long source duration must be at least partially responsible for the long duration ground motion observed in the severely damaged zone in Mexico City.

The 21 September 1985 aftershock. Only a few $P$ waveforms of the large $M_{S} 7.5$ aftershock on 21 September are available. The waveforms are consistent with a mechanism identical to the main shock, with a slightly greater source depth of 22 $\mathrm{km}$ (Figure 7). The aftershock time function is a single source with a duration of $13 \mathrm{sec}$. The seismic moment recovered from the body waves is $1.2 \times 10^{27}$ dyne-cm.

The 30 April 1986 aftershock. Long period $P$ waves of the aftershock which occurred in 30 April 1986 from 15 WWSSN stations are shown in Figure 8. The synthetic seismograms are calculated for a point source $21 \mathrm{~km}$ deep and sourcetime duration of $10 \mathrm{sec}$. First motion data constrain only one of the nodal planes as is common for most large Mexican subduction events. The second fault plane was resolved from waveform modeling. The fault parameters determined are $\theta=280^{\circ}, \delta$ $=12^{\circ}$, and $\lambda=70^{\circ}$. The seismic moment for each station is given next to the station code. The values within parentheses are obtained from diffracted $P$ arrivals and are not used to determine the average seismic moment that is $2.0 \times 10^{26}$ dyne-cm. This value is consistent with that $\left(3.1 \times 10^{26}\right.$ dyne-cm) obtained by the Harvard longperiod centroid-moment tensor inversion (Dziewonski and Woodhouse, 1983) and published by the National Earthquake Information Center.

The 1981 Playa Azul earthquake. Modeling of 17 long-period WWSSN $P$ waves of the 25 October 1981 Playa Azul earthquake indicates that this event has two point sources at $27 \mathrm{~km}$ depth, with a total duration of $15 \mathrm{sec}$ as shown in Figure 9. The first source contributes to 15 per cent of the total seismic moment. The fault

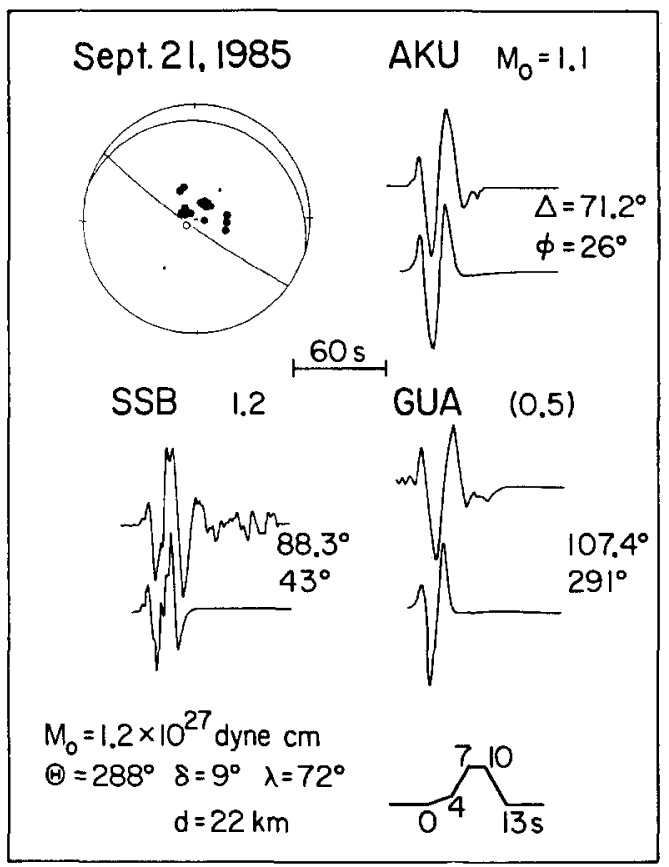

Fig. 7. Observed (above) and calculated $P$ waves for the aftershock of 21 September. The recordings are from a broadband GEOSCOPE (SSB) and long-period WWSSN stations at teleseismic distances. The observed waveforms are matched with the focal mechanism shown and a simple 13-sec long trapezoidal source-time function at $22 \mathrm{~km}$ depth. 


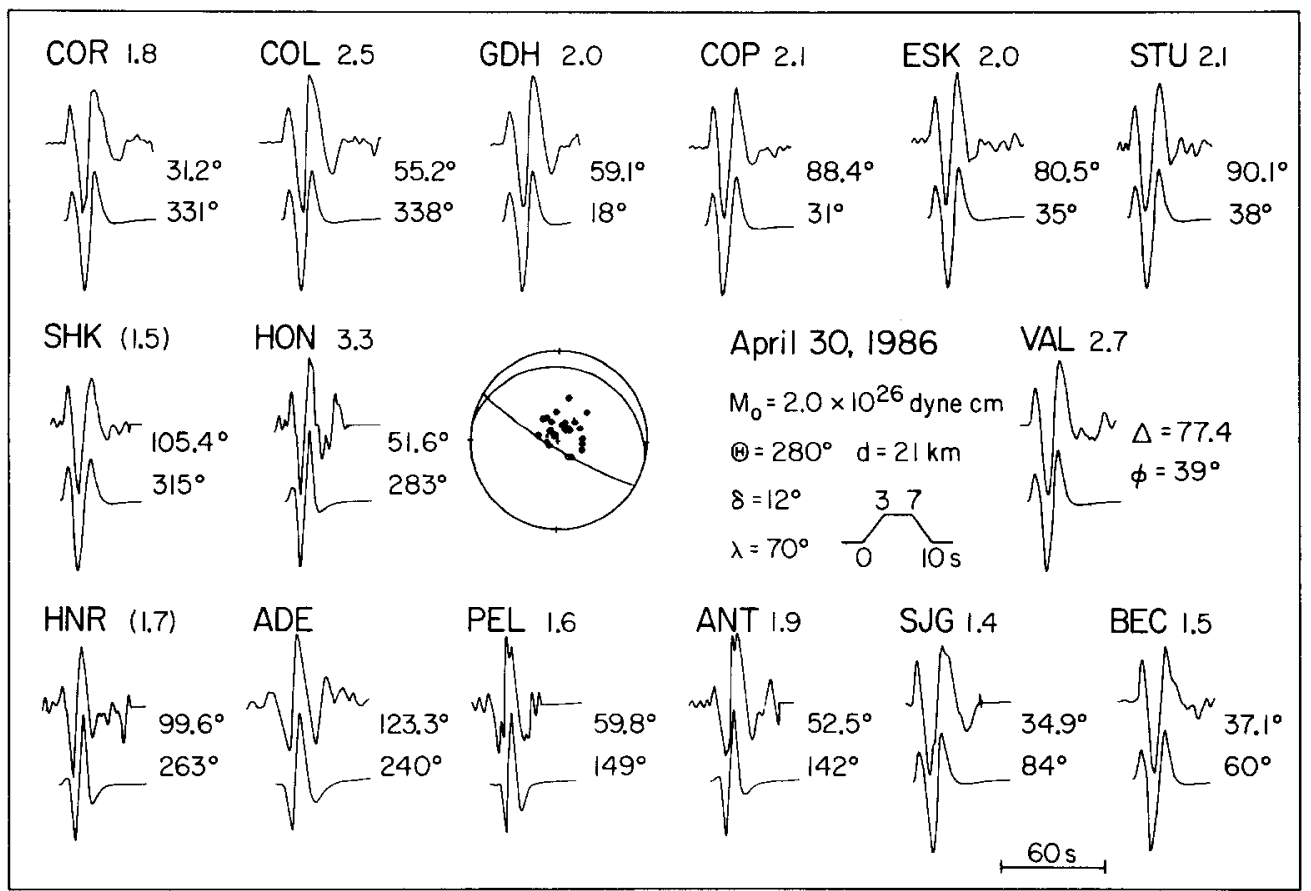

FIG. 8. Long-period WWSSN recordings of $P$ waves for the 30 April $1986\left(M_{W}=6.9\right)$ earthquake are shown by the upper traces. Distance and azimuth to each station are indicated as well as the seismic moment obtained for each station. The synthetic seismograms (lower traces) are calculated using the fault parameters shown and a point source at $21 \mathrm{~km}$ depth and 10 -sec long source-time function.

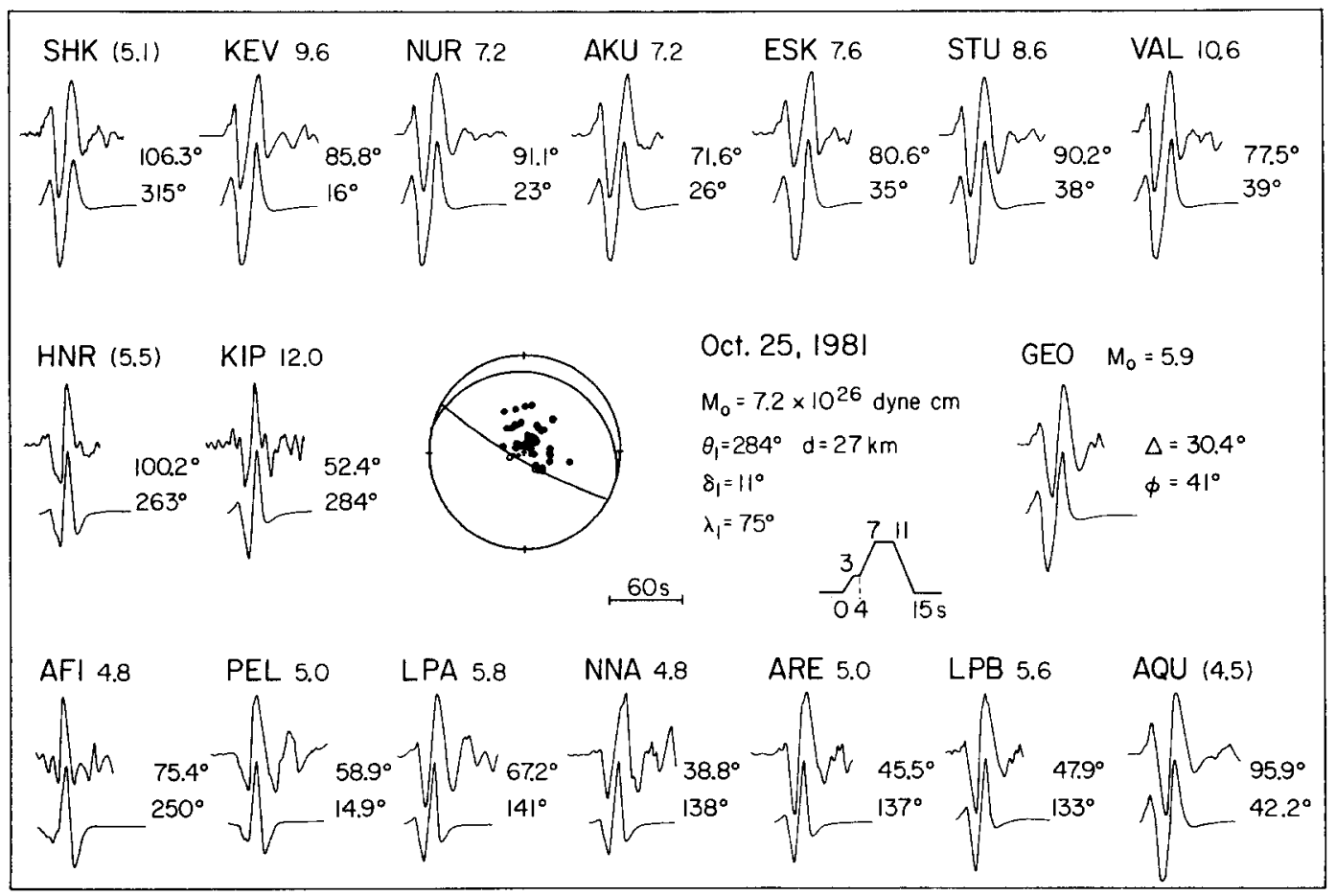

FIG. 9. Upper traces (observed) are long-period WWSSN $P$ waves of the 25 October 1981 Playa Azul $\left(M_{W}=7.3\right)$ earthquake. The synthetic seismograms (lower traces) are for a double source $27 \mathrm{~km}$ deep and the shallow thrust fault mechanism shown. The first source contributes 15 per cent of the total seismic moment $M_{0}=7.2 \times 10^{26}$ dyne-cm. 
parameters determined from the $P$ waves are $\theta=285^{\circ}, \delta=11^{\circ}$, and $\lambda=75^{\circ}$, and are consistent with previous studies (Havskov et al., 1983; LeFevre and McNally, 1985). The average seismic moment recovered from nondiffracted $P$ waves is $7.2 \times$ $10^{26}$ dyne-cm. The epicenter given by Havskov et al. (1983) for the Playa Azul event $\left(17.75^{\circ} \mathrm{N}, 102.25^{\circ} \mathrm{W}\right)$ had a fixed depth at $20 \mathrm{~km}$; however, the aftershocks with good depth determinations were as deep as $26 \mathrm{~km}$. They also point out that the aftershocks are clustered in two distinct groups on either side of the main shock location, suggesting the presence of two asperities. This result is also consistent with the source-time function determined above.

\section{Determination of Seismic Moment from Long-Period Surface Waves}

Long-period surface waves recorded by the GDSN, Regional Seismic Test Network, and International Deployment of Accelerographs (IDA) networks are used to determine the seismic moment of the Michoacan earthquakes. We use the amplitude and phase spectra at a period of 256 sec from multiple passages of Rayleigh and Love waves with an inversion method described by Kanamori and Given (1981). Table 3 shows the stations and phases used for the September Michoacan earthquakes. Since the result has already been published in Eissler et al. (1986), we summarize it in Table 1 . The mechanism solution is very close to the body-wave focal mechanism shown in Figure 4, with a difference of only $7^{\circ}$ in fault strike and $6^{\circ}$ in slip angle. The seismic moment is $M_{0}=1.7 \times 10^{28}$ dyne-cm with an assumed source depth of $10 \mathrm{~km}$. We find that the errors in the inversion are minimized with a source process time $\tau=100 \mathrm{sec}$ for a period of $256 \mathrm{sec}$. A simultaneous inversion of long-period surface waves at different periods (150 to $300 \mathrm{sec})$ gives $\tau=80 \mathrm{sec}$ for the Michoacan earthquake (Zhang and Kanamori, 1987).

TABLE 3

Stations Used in the Surface-Wave Inversion

\begin{tabular}{|c|c|c|c|c|c|}
\hline $\begin{array}{l}\text { Station } \\
\text { Code }\end{array}$ & Station Name & $\begin{array}{c}\text { Distance } \\
\left({ }^{\circ}\right)\end{array}$ & $\begin{array}{c}\text { Azimuth } \\
\left({ }^{\circ}\right)\end{array}$ & 19 September 1985 & 21 September 1985 \\
\hline ALE & Alert, Canada & 66.1 & 5.3 & $R 3, R 4$ & $R 2, R 3$ \\
\hline RSON* & Red Lake, Canada & 33.3 & 10.2 & $R 2, R 3, G 2, G 3$ & \\
\hline ESK & Eskdalemuir, Scotland & 80.3 & 34.9 & $R 2, R 3$ & $R 2, R 3$ \\
\hline RSNY* & Adirondack, New York & 35.1 & 35.6 & $R 2, R 3$ & \\
\hline $\mathrm{SCP}+$ & State College, Pennsylvania & 30.8 & 38.1 & $R 2, R 3$ & \\
\hline HAL & Halifax, Canada & 41.7 & 42.3 & $R 2, R 3$ & $R 2, R 3$ \\
\hline SJG & San Juan, Puerto Rico & 34.5 & 84.4 & $R 2, R 3$ & $R 2, R 3$ \\
\hline SUR & Sutherland, RSA $\ddagger$ & 127.4 & 117.1 & $R 3, R 4$ & $R 2, R 3$ \\
\hline BDF & Brasilia, Brasil & 63.4 & 118.6 & $R 2, R 3$ & $R 2, R 3$ \\
\hline NNA & Nana, Peru & 39.3 & 138.0 & $R 2, R 3$ & $R 2, R 3$ \\
\hline RAR & Rarotonga, Cook Islands & 68.5 & 237.6 & $R 3, R 4$ & $R 2, R 3$ \\
\hline TWO & Adelaide, Australia & 123.7 & 239.7 & $R 3, R 4$ & $R 2, R 3$ \\
\hline HON† & Honolulu, Hawaii & 49.8 & 280.3 & $R 2, R 3, G 2, G 3$ & \\
\hline KIP & Kipapa, Hawaii & 52.1 & 283.2 & $R 2, R 3$ & $R 2, R 3$ \\
\hline GUA & Guam, Mariana Islands & 106.4 & 290.6 & $R 2, R 3$ & $R 2, R 3$ \\
\hline ERM & Erimo, Japan & 94.8 & 317.0 & $R 2, R 3$ & $R 2, R 3$ \\
\hline BJT & Bejin, China & 111.7 & 328.9 & $R 3, R 4$ & $R 2, R 3$ \\
\hline $\mathrm{COL} \dagger$ & College, Alaska & 55.5 & 338.4 & $R 2, R 3, G 2, G 3$ & \\
\hline ANMO $\dagger$ & Albuquerque, New Mexico & 17.0 & 348.8 & $R 2, R 3$ & \\
\hline RSNT* & Yellowknife, Canada & 45.0 & 352.1 & $R 2, R 3, G 2, G 3$ & \\
\hline $\mathrm{RSSD}^{*}$ & Black Hills, South Dakota & 25.8 & 357.4 & $R 2, R 3, G 2, G 3$ & \\
\hline
\end{tabular}

* Regional Seismic Test Network.

+ GDSN and IDA networks.

$\ddagger$ RSA $=$ Republic of South Africa. 
For the aftershock, we used 26 Rayleigh wave phases from the IDA network, holding the auxiliary plane fixed at the orientation from the main shock firstmotion data. The inversion returned a fault orientation of $\delta=9.5^{\circ}, \theta=289^{\circ}$, and $\lambda$ $=73^{\circ}$, essentially the same as the main shock, with a seismic moment of $4.7 \times 10^{27}$ dyne-cm, 28 per cent that of the main shock, and a source process time $\tau=60$ sec. Figure 10 shows the observed and calculated Rayleigh wave radiation pattern for the aftershock.

LeFevre and McNally (1985) inverted 256-sec surface waves of the 1981 Playa Azul earthquake. They constrained the steeply dipping nodal plane $\left(\delta=79^{\circ}\right)$ using the moment tensor technique described in Kanamori and Given (1981) and determined the long-period seismic moment $\left(M_{0}=1.3 \times 10^{27}\right.$ dyne-cm). The solution given by Harvard and published by the National Earthquake Information Center for this event is $\theta=287^{\circ}, \operatorname{dip}=20^{\circ}, \lambda=82^{\circ}$, and $M_{0}=7.0 \times 10^{26}$ dyne-cm with a centroid depth of $32 \mathrm{~km}$.

If the auxiliary plane is tightly constrained to have a steep dip from the firstmotion data, then the fault plane returned by the inversion will have a shallow dip for any mechanism that is predominantly thrust. By relaxing this constraint, the inversion for the long-period source might return a fault plane orientation with a slightly different dip angle. For shallow thrust events, the seismic moment determined from the surface-wave inversion, $M_{0}$, depends on the dip angle $\delta$ as $M_{0}=$ $M_{0_{\min }} / \sin 2 \delta$ where $M_{0_{\min }}$ is the minimum seismic moment (Kanamori and Given, 1982). Thus, for a dip of $15^{\circ}$ instead of $9^{\circ}$, the moment is smaller by about a factor of 1.6. For a mechanism with a maximum fault plane dip of $15^{\circ}$ and a minimum of $9^{\circ}$, for the main shock the moment ranges from 1.05 to $1.70 \times 10^{28}$ dyne-cm or $M_{W}$ $=7.9$ to 8.1 , respectively. Locations of aftershocks from local networks define a dip of approximately $12^{\circ}$ to $14^{\circ}$ (Stolte et al., 1986; UNAM Seismology Group, 1986), indicating that the lower end of the range is more appropriate. For the aftershock, the moment range is 2.9 to $4.7 \times 10^{27}$ dyne-cm or $M_{W}=7.6$ to 7.7 .

Results of other studies of the long-period source of the 1985 Michoacan earthquake compare favorably with those presented here and are summarized in Table 4. Details of the solutions vary due to differences in the data sets, techniques, constraints on the solutions, or earth models used. In particular, different approaches can be taken to provide control on the poorly determined components of the moment tensor. All of the studies found an overall thrust geometry (rake angles deviating from $2^{\circ}$ to $17^{\circ}$ from pure thrust) on a fault plane striking parallel to the Middle America trench $\left(\mathrm{N} 289^{\circ} \mathrm{E}\right.$ to $\left.\mathrm{N} 302^{\circ} \mathrm{E}\right)$. Shallow dip angles $\left(<20^{\circ}\right)$ were determined or inferred in all of the studies. In view of the dependence of the seismic moment value on fault-plane dip angle, we correct the values in Table 4 to correspond to a dip angle of $15^{\circ}$ for comparison. Values of seismic moment are then

TABLE 4

Results of LONG-PERIOd Studies

\begin{tabular}{lcrrrr}
\hline & $\begin{array}{c}\delta \\
\left(^{\circ}\right)\end{array}$ & $\begin{array}{c}\phi \\
\left(^{\circ}\right)\end{array}$ & $\begin{array}{c}\lambda \\
\left({ }^{\circ}\right)\end{array}$ & $\begin{array}{c}M_{0} \\
\left(\times 10^{28}\right. \\
\text { dyne-cm })\end{array}$ & $\begin{array}{c}M_{0} \text { at } \\
\delta=15^{\circ} \\
\left(\times 10^{28}\right. \\
\text { dyne-cm })\end{array}$ \\
\hline $\begin{array}{l}\text { This study } \\
\begin{array}{l}\text { Ekstrom and Dziewonski } \\
\quad(1986)\end{array}\end{array}$ & 9 & 295 & 78 & 1.70 & 1.05 \\
$\begin{array}{l}\text { Priestley and Masters } \\
\quad(1986)\end{array}$ & 15 & 302 & 107 & 1.10 & 1.29 \\
$\begin{array}{l}\text { Riedesel et al. }(1986) \\
\text { (fixed) }\end{array}$ & 298 & 88 & 1.03 & 1.03 \\
& $19 \pm 15$ & 289 & 76 & 1.07 & 1.32
\end{tabular}


very consistent, varying from 1.03 to $1.32 \times 10^{28}$, with an average value of $1.17 \times$ $10^{28}$ dyne-cm or $M_{W}=8.0$.

Riedesel et al. (1986) determined the characteristic time, $\tau_{c}$, for the September earthquakes from the scalar-moment algorithm of Silver and Jordan (1983) and obtained $\tau_{c}=49 \pm 7 \mathrm{sec}$ for the main event and $30 \pm 11 \mathrm{sec}$ for the aftershock. This compares favorably with the source process times, $\tau$, resolved above because $\tau=$ $1.73 \tau_{c}$ (Silver and Jordan, 1983).

\section{INFERRED STRESS Drops FOR MeXican EARTHQUakes}

Since earthquake stress drop is a useful parameter to characterize earthquakes, we compare stress drops determined for Mexican subduction zone events. Earthquake stress drops are usually determined from the seismic moment, $M_{0}$, and the fault area. However, as discussed above, $M_{0}$ of shallow thrust earthquakes depends on the dip angle assumed. The fault area, $S$, is often estimated from the aftershock area, but its definition varies for different investigators. Due to these uncertainties, it is hard to estimate the error associated with a single stress drop value and to compare the published values for different events.

To circumvent this difficulty, we compare the seismic moments and the fault areas estimated for large earthquakes in the Mexican subduction zone and examine the overall trend on a $\log S$ versus $\log M_{0}$ diagram. Figure 11 shows the data we used. The horizontal bars attached to each data point indicate the range of seismic moment estimated from body and surface waves for events listed in Table 5. The

TABLE 5

Source Parameters of LaRge Shallow Interplate Mexico Earthquakes

\begin{tabular}{|c|c|c|c|c|c|c|c|c|c|}
\hline No. & Date & $\begin{array}{l}\text { Latitude } \\
\left({ }^{\circ} \mathrm{N}\right)\end{array}$ & $\begin{array}{l}\text { Longitude } \\
\left({ }^{\circ} \mathrm{W}\right)\end{array}$ & $\begin{array}{c}\text { Depth } \\
(\mathrm{km})\end{array}$ & $M_{S}$ & $M_{w}$ & $\begin{array}{l}M_{o b} \\
\left(\times 10^{2 n}\right.\end{array}$ & $\begin{array}{r}M_{\infty} \\
\text { ne-cm) }\end{array}$ & $L \times W\left(\mathrm{~km}^{2}\right)$ \\
\hline 1 & 3 Jun. 1932 & 19.57 & $104.42^{\mathrm{a}}$ & $16^{c}$ & $8.2^{\mathrm{b}}$ & 7.9 & $3.12^{c}$ & $9.1^{\mathrm{d}}$ & $170 \times 80^{\mathrm{e}}$ \\
\hline 2 & 18 Jun. 1932 & 19.50 & $103.50^{f}$ & $13^{c}$ & $7.8^{b}$ & 7.8 & $2.10^{c}$ & $7.3^{d}$ & $60 \times 80^{e}$ \\
\hline 3 & 23 Dec. 1937 & 17.10 & $98.07^{\mathrm{g}}$ & $16^{c}$ & $7.5^{\mathrm{f}}$ & 7.4 & $0.44^{c}$ & $1.53^{\mathrm{c}}$ & $120 \times 70^{8}$ \\
\hline 4 & 15 Apr. 1941 & 18.85 & $102.94^{\mathrm{g}}$ & $S$ & $7.7^{\mathrm{f}}$ & & & $4.4^{\mathrm{h}}$ & $60 \times 50^{\mathrm{g}}$ \\
\hline 5 & 22 Feb. 1943 & 17.62 & $101.15^{\mathrm{g}}$ & $16^{\mathrm{c}}$ & $7.5^{f}$ & 7.4 & $0.45^{c}$ & $1.59^{\mathrm{c}}$ & $75 \times 60^{\mathrm{s}}$ \\
\hline 6 & 14 Dec. 1950 & 17.22 & $98.12^{\mathrm{g}}$ & $20^{\mathrm{c}}$ & $7.3^{f}$ & 7.1 & $0.48^{c}$ & $0.60^{c}$ & $80 \times 70^{\mathrm{g}}$ \\
\hline 7 & 28 Jul. 1957 & 17.11 & $99.10^{8}$ & $16^{\mathrm{c}}$ & $7.5^{\mathrm{i}}$ & 7.6 & $0.85^{c}$ & $3.3^{\mathrm{j}}$ & $100 \times 65^{\mathrm{g}}$ \\
\hline 8 & 23 Aug. 1965 & 16.02 & 95.93 & $25^{k}$ & $7.6^{1}$ & 7.5 & $1.9^{1}$ & $1.7^{1}$ & $105 \times 46^{k}$ \\
\hline 9 & 2 Apr. 1968 & 16.39 & 98.06 & $21^{k}$ & $7.1^{\mathrm{f}}$ & 7.3 & $0.8^{1}$ & $1.0^{1}$ & $50 \times 82^{k}$ \\
\hline 10 & 29 Apr. 1970 & 14.52 & 92.60 & 33 & $7.3^{\mathrm{f}}$ & 7.4 & $0.5^{1}$ & $1.2^{\mathrm{l}}$ & $130 \times 96^{\mathrm{m}}$ \\
\hline 11 & 30 Jan. 1973 & 18.39 & 103.21 & $32^{\mathrm{n}}$ & $7.5^{f}$ & 7.6 & & $3.0^{l}$ & $90 \times 63^{n} \uparrow$ \\
\hline 12 & 29 Nov. 1978 & 15.77 & 96.80 & $18^{k}$ & $7.8^{f}$ & 7.6 & $1.9^{\mathrm{l}}$ & $3.2^{1}$ & $82 \times 60^{k}$ \\
\hline 13 & 14 Mar. 1979 & 17.45 & 101.45 & $14^{\circ}$ & $7.6^{\mathrm{f}}$ & 7.6 & $1.0^{1}$ & $2.7^{1}$ & $65 \times 45^{p}$ \\
\hline 14 & 25 Oct. 1981 & 17.75 & 102.25 & $27^{\mathrm{t}}$ & $7.3^{\mathrm{f}}$ & 7.3 & $0.72^{t}$ & $1.4^{\mathrm{r}}$ & $40 \times 20^{\mathrm{q}}$ \\
\hline 15 & 7 Jun. $1982^{*}$ & 16.40 & 98.54 & $S$ & $7.0^{\mathrm{f}}$ & 7.1 & $0.40^{\mathrm{s}}$ & $0.50^{\mathrm{s}}$ & $78 \times 41^{f}$ \\
\hline 16 & 19 Sept. 1985 & 18.27 & $102.31^{f}$ & $17^{\mathrm{t}}$ & $8.1^{f}$ & 8.0 & $7.2^{\mathrm{t}}$ & $10.5^{t}$ & $170 \times 50^{\mathrm{u}}$ \\
\hline 17 & 21 Sept. 1985 & 17.81 & $101.65^{f}$ & $22^{t}$ & $7.5^{f}$ & 7.6 & $1.2^{\mathrm{t}}$ & $2.9^{t}$ & $66 \times 33^{\mathrm{u}}$ \\
\hline
\end{tabular}

The abbreviations used are: $\mathrm{N}=$ event number in Figure $12 ; M_{o b}=$ seismic moment from body waves; $M_{o s}=$ seismic moment from surface waves; $L \times W=$ fault length and width for 1 -week aftershock area; $M_{w}=$ determined from $M_{o s} ;{ }^{*}=$ doublet event.

References: $\mathrm{a}=$ Eissler and McNally (1984); $\mathrm{b}=$ Geller and Kanamori (1977); $\mathrm{c}=$ Singh et al. (1984) $\mathrm{d}=$ Wang et al. (1982); $\mathrm{e}=$ Singh et al. (1985); $\mathrm{f}=$ NOAA; $\mathrm{g}=$ Kelleher et al. (1973); $\mathrm{h}=$ determined from $M_{S} ; \mathrm{i}=$ Abe and Kanamori (1981); $\mathrm{j}=$ Singh et al. (1982); $\mathrm{k}=$ Tajima and McNally (1983); $1=$ Chael and Stewart (1982); $m=$ Yamamoto (1978) (12-hr aftershock area); $n=$ Reyes et al. (1979) (†2.5week aftershock area); $0=$ Gettrust et al. (1981); $\mathrm{p}=$ Valdés et al. (1982) $\mathrm{q}=$ Havskov et al. $(1983) ; \mathrm{r}=$ LeFevre and McNally (1985); $s=$ Astiz and Kanamori (1984); $t=$ this study; and $u=U N A M$ Seismology Group (1985). 

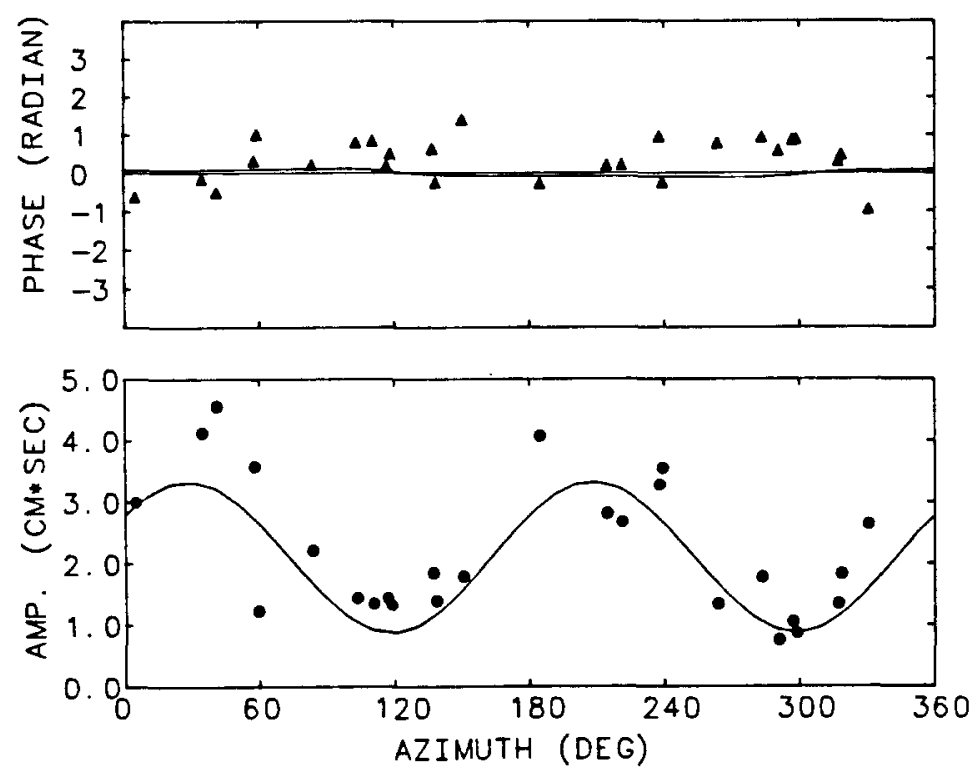

FIG. 10. Observed phase (triangles) and amplitude (circles) spectral values as a function of azimuth of Rayleigh wave data from IDA stations used in the surface-wave inversion, compared with the theoretical pattern for the best-fitting solution for the large 21 September aftershock. Spectral values are for a period $T=256 \mathrm{sec}$.

fault dimensions correspond, in most cases, to the 1-week aftershock area. The vertical bars indicate the range of the values calculated for a rectangular and elliptic shape for $S$. Closed symbols indicate the events for which the moment determination was made from at least several WWSSN seismograms (i.e., events after 1963). Lines in Figure 10 indicate the trends for equal static stress drop calculated for a circular crack model. If a rectangular dip-slip model is used, with an aspect ratio (length/ width) of 1.5 (the average for the Mexican subduction zone events), the stress drop values in Figure 11 should be multiplied by 0.4 .

Although the uncertainties in $M_{0}$ and $S$ are large, Figure 11 suggests that some events near the Orozco fracture zone have larger stress drops ( $>50$ bars). Those events are the Petatlan earthquakes in 1941 and 1979 (events 4 and 13), the 21 September 1985, Michoacan, earthquake aftershock (event 17), and the 1981 Playa Azul earthquake (event 14). This may be due to an increased interplate interaction as the seafloor of the Orozco fracture zone, which is probably more buoyant than the adjacent seafloor, subducts in this area. The 19 September main shock (event 16) has a lower stress drop than these events.

Anderson et al. (1986) determined from strong ground motion records that the apparent stress drop (Aki, 1966) of the main 1985 Michoacan earthquake which is a measure of the average stress drop on the fault is 6 bars. They also determined that effective dynamic stress drop (Brune, 1970) varies from 6 to 12 bars for the main event. Although the apparent stress and the effective stress cannot be directly related to the static stress drop, these low values are generally consistent with the low static stress drop inferred from Figure 11. These low stress drop values correlate with the low amplitude strong ground motions $(\approx 0.15 \mathrm{~g}$ on the north-south and east-west components) recorded at hard rock sites in the epicentral area (Anderson et al., 1986). For the 1981 Playa Azul $\left(M_{S}=7.3\right)$ earthquake, larger accelerations ( $0.24 \mathrm{~g}$ on the east-west component) were recorded at hard rock sites near the 


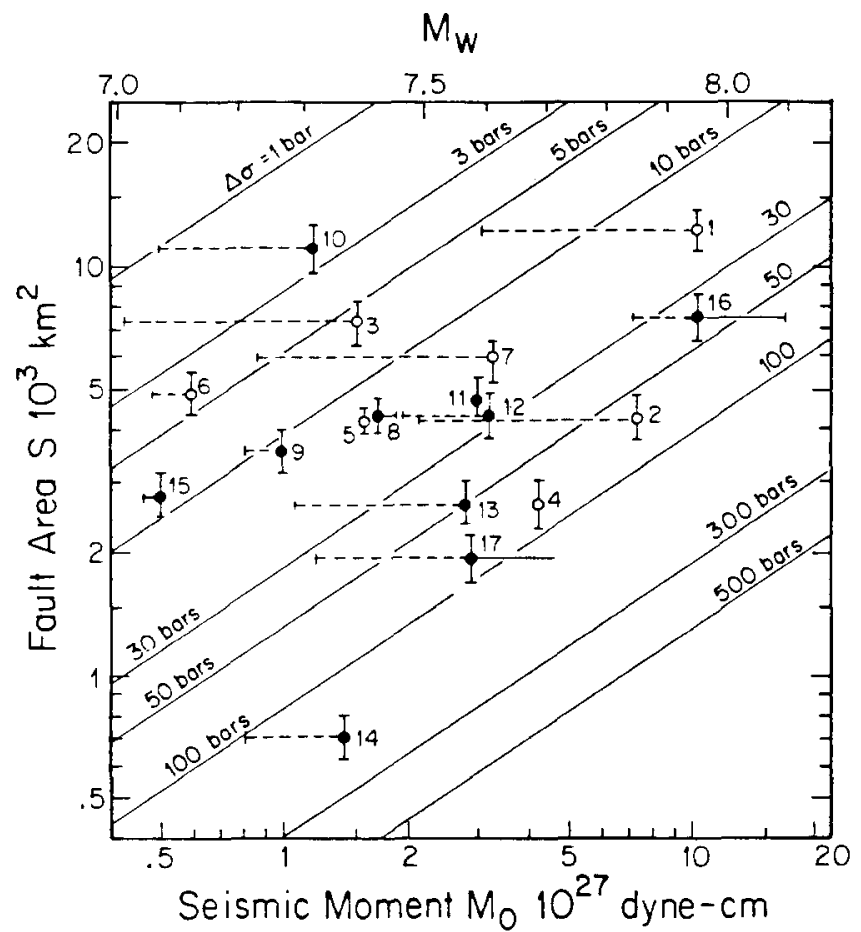

FIG. 11. Plot of seismic moment, $M_{0}$, versus fault area, $S$, for large Mexican subduction earthquakes since 1932. The range of values determined from body and surface waves for $M_{0}$ are indicated by the error bars. Error bars for $S$ are for rectangular and elliptical areas. Open symbols are events before the installation of the WWSSN stations. Event numbers correspond to those in Table 4. Lines are constant static stress drop $(\Delta \sigma)$ calculated for a circular crack. Uncertainties in the data are too large to assign a unique stress drop value to each event.

epicenter (Havskov et al., 1983). Figure 11 shows a relatively higher stress drop value for the Playa Azul event (14) than for the 1985 Michoacan main event (16). This observation suggests that possible variations in stress drops need to be considered for estimating strong ground motions from future Mexican subduction zone earthquakes.

\section{Relation between Recurrence Time and Seismic Moment}

Astiz and Kanamori (1984) noted an empirical relation between the average seismic moment per region and the average recurrence time per region for large earthquakes in the Mexico subduction zone

$$
\log T=\frac{1}{3} \log M_{0}-7.5,
$$

where $T$ is in years and $M_{0}$ in dyne-cm. Using 1911 as the last event date in the Michoacan gap, their relation predicts a seismic moment of $1.3 \times 10^{28}$ dyne-cm for an event in 1985, which is within the moment range found for the Michoacan earthquake. Astiz and Kanamori based their relation on activity in the GuerreroOaxaca region of the subduction zone and noted that it did not hold north of the Michoacan gap; we can now tentatively extend it into the Michoacan area (Figure 12 ). Since the last large Guerrero events occurred about the turn of the century, equation (2) implies that an impending event in the Guerrero gap would have a large seismic moment similar to the Michoacan earthquake. In deriving the $T-M_{0}$ 


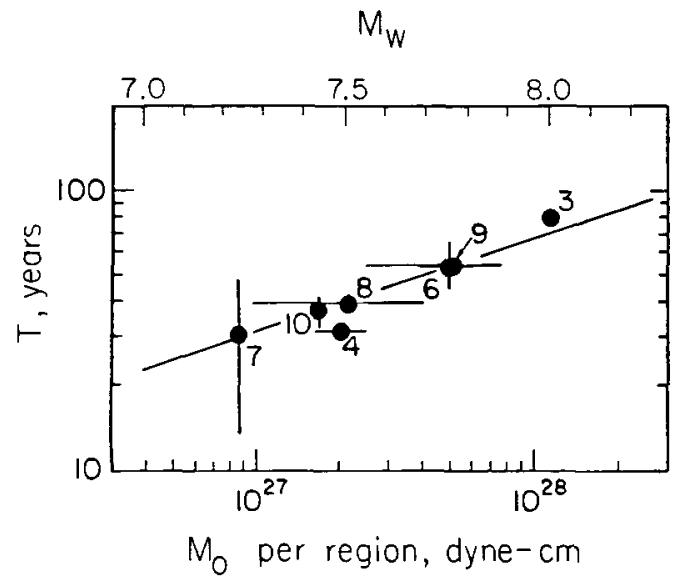

FIG. 12. Plot of average moment per region, $\bar{M}_{0}$, versus recurrence period, $T$, along the Mexican subduction zone (adapted from Astiz and Kanamori, 1984). Numbers correspond to regions in Figure 2. The line has a slope of $\frac{1}{3}$, suggesting that the relation $\log T=\frac{1}{3} \log M_{0}$ holds for events that have occurred along the zone from Michoacan to Oaxaca. The 1985 Michoacan earthquake (region 3 ) fits the general trend.

relation, seismic moments of earthquakes occurring within $3 \mathrm{yr}$ of each other were added together and considered as one event; $3 \mathrm{yr}$ is approximately 10 per cent of the average recurrence period in the region (McNally and Minster, 1981). Thus, the relation does not distinguish between single large earthquakes or sequences of smaller events closely spaced in time. Using 1907 as the last date for an event in Guerrero, the relation predicts that an impending episode would involve $1.6 \times 10^{28}$ dyne-cm. This is equivalent to one earthquake with a moment magnitude of 8.1 , or alternatively, three of $M_{W}=7.8$. Both scenarios have serious implications for damage in Mexico City.

\section{CONCLUSIONS}

The rupture pattern of the Michoacan gap during the period of 1981 to 1986 can be characterized by a sequential failure of five distinct asperities, as schematically shown in Figure 1. Before 1981, the Michoacan gap had not experienced a large earthquake since 1911 when an $M_{S}=7.9$ earthquake occurred. The recent sequence started in October 1981 with the Playa Azul $\left(M_{W}=7.3\right)$ earthquake which broke the central part of the Michoacan gap. The Playa Azul event is slightly deeper than the recent Michoacan earthquakes in September 1985 and April 1986. In addition, the stress drop of this event is higher than other events in this gap, suggesting a higher concentration of stress at depth in the middle of the Michoacan gap.

The seismic moment of the 19 September $1985\left(M_{W}=8.1\right)$ earthquake was released in two distinct events, with the rupture starting in the northern portion of the seismic gap and propagating to the southeast with low moment release through the area already broken by the 1981 Playa Azul earthquake. Then, on 21 September 1985 , the rupture propagated further southeast with an $M_{W}=7.5$ event, that may have broken the shallower portion of the subduction zone up-dip of the 1979 Petatlan $\left(M_{W}=7.6\right)$ earthquake (UNAM Seismology Group, 1986). The location of the 30 April $1986\left(M_{W}=6.9\right)$ aftershock northwest of the main shock (Figure 1) suggests that it released the remaining stress between the 1973 Colima $\left(M_{W}=7.6\right)$ earthquake and the September events. 
Although this distribution of asperities is considered characteristic of the Michoacan gap, whether the temporal sequence exhibited by the 1981 to 1986 sequence is also characteristic of this gap or not is unclear. In fact, there is no obvious evidence that the 1911 event occurred in a similar sequence. It is probable that, depending on the state of stress in each asperity, the entire gap may fail in either a single large event with a complex time history or a sequence of moderate to large events spread over a few years. If a similar model is applicable to the adjacent Guerrero gap, we should expect a similar variation in the failure mode of the next Guerrero earthquake.

The seismic moment of the 1985 Michoacan earthquake is consistent with an empirical relation between average seismic moment per region in one recurrence period and regional recurrence time found for the Mexico subduction zone by Astiz and Kanamori (1984). This relation predicts a comparably large moment for the next event in the Guerrero gap.

\section{ACKNOWLEDGMENTS}

We would like to thank personnel at many WWSSN stations, Project GEOSCOPE of Institut de Physique du Globe in Paris, Project IDA at Institute for Geophysics and Planetary Physics at the University of California, San Diego, the Center for Seismic Studies in Washington, D.C., and the U.S. Geological Survey for making their data available to us. We benefited from discussions with colleagues at the special session on the Michoacan earthquake at the American Geophysical Union Meeting, Fall 1985. David M. Boore provided helpful suggestions that improved an earlier version of this manuscript. This research was supported by Grants from the U.S. Geological Survey 14-09-0001-G1170 and NSF ECE-86-10994.

\section{REFERENCES}

Abe, K. (1973). Tsunami and mechanism of great earthquakes, Phys. Earth Planet. Interiors 7, 143-153. Abe, K. and H. Kanamori (1980). Magnitude of great shallow earthquakes from 1953-1977, Tectonophysics 62, 191-203.

Aki, K. (1966). Generation and propagation of $G$ waves from the Niigata earthquake of June 16, 1964. 2. Estimation of earthquake movement, released energy and stress-strain drop from $G$ wave spectrum, Bull. Earthquake Res. Inst., Tokyo Univ. 4, 23-88.

Anderson, J. G., P. Bodin, J. N. Brune, J. Prince, S. K. Singh, R. Quaas, and M. Onate (1986). Strong ground motion and source mechanism of the Mexico earthquake of September $19,1985\left(M_{S}=8.1\right)$, Science 233, 1043-1049.

Astiz, L. and H. Kanamori (1984). An earthquake doublet in Ometepec, Guerrero, Mexico, Phys. Earth Planet. Interiors 34, 24-45.

Branner, J. (1912). Reviews, Bull. Seism. Soc. Am. 3, 12.

Brune, J. N. (1970). Tectonic stress and the spectra of seismic shear waves from earthquakes, J. Geophys. Res. 75, 4997-5009.

Chael, E. P. and G. S. Stewart (1982). Recent large earthquakes along the Middle-American trench and their implications for the subduction process, J. Geophys. Res. 87, 329-338.

Dziewonski, A. M. and J. H. Woodhouse (1983). An experiment in the systematic study of global seismicity; centroid-moment tensor solutions for 201 moderate and large earthquakes of $1981, J$. Geophys. Res. 88, 3247-3271.

Eissler, H. and K. McNally (1982). Seismicity and tectonics of the Rivera plate and implications for the 1932 Jalisco, Mexico earthquake, J. Geophys. Res. 89, 4520-4530.

Eissler, H., L. Astiz, and H. Kanamori (1986). Tectonic setting and source parameters of the September 19, 1985 Michoacan, Mexico, earthquake, Geophys. Res. Letters 13, 569-572.

Ekstrom, G. and A. M. Dziewonski (1986). A very broad band analysis of the Michoacan, Mexico, earthquake of September 19, 1985, Geophys. Res. Letters 13, 605-607.

Figueroa, J. A. (1959). New seismic chart of Mexico, Anales del Instituto de Geofisica, Universidad Nacional Autonoma de México 5, 45-162.

Geller, R. J. and H. Kanamori (1977). Magnitude of great shallow earthquakes from 1904-1952, Bull. Seism. Soc. Am. 67, 587-598.

Gettrust, J. F., V. Hsu, C. E. Helsley, E. Herrero, and T. Jordan (1981). Patterns of local seismicity 
preceeding the Petatlan earthquake of March 14, 1979, Bull. Seism. Soc. Am. 71, 761-769.

Goodstein, J. R., H. Kanamori, and W. Lee (1980). Seismology microfiche publications from the Caltech archives, Bull. Seism. Soc. Am. 70, 657-658.

Gutenberg, B. and C. F. Richter (1954). Seismicity of the Earth and Associated Phenomena, Princeton University Press, Princeton, New Jersey, $135 \mathrm{pp}$.

Havskov, J., S. K. Singh, E. Nava, T. Dominguez, and M. Rodriguez (1983). Playa Azul, Michoacan, Mexico, earthquakes of 25 October, $1981\left(M_{S}=7.3\right)$, Bull. Seism. Soc. Am. 73, 449-458.

Houston, H. and H. Kanamori (1986). Source characteristics of the 1985 Michoacan, Mexico earthquake at short periods, Geophys. Res. Letters 13, 597-600.

Kanamori, H. and G. S. Stewart (1976). Mode of strain release along the Gibbs fracture zone, MidAtlantic Ridge, Phys. Earth Planet. Interiors 11, 312-332.

Kanamori, H. and J. W. Given (1981). Use of long-period surface waves for rapid determination of earthquake source parameters, Phys. Earth Planet. Interiors 27, 8-31.

Kanamori, H. and J. W. Given (1982). Use of long-period surface waves for rapid determination of earthquake source parameters. 2. Preliminary determination of source mechanisms of large earthquakes $\left(M_{S} \geq 6.5\right)$ in 1980, Phys. Earth Planet. Interiors 30, 260-268.

Kelleher, J. and W. R. McCann (1976). Buoyant zones, great earthquakes and unstable boundaries of subduction, J. Geophys. Res. 81, 4885-4896.

Kelleher, J., L. Sykes, and J. Oliver (1973). Possible criteria for predicting earthquake locations and their application to major plate boundaries of the Pacific and the Caribbean, J. Geophys. Res. 78, $2547-2585$.

Langston, C. A. and D. V. Helmberger (1975). A procedure for modeling shallow dislocation sources, Geophys. J. R. Astr. Soc. 42, 117-130.

LeFevre, L. V. and K. C. McNally (1985). Stress distribution and subduction of aseismic ridges in the Middle America subduction zone, J. Geophys. Res. 90, 4495-4510.

McCann, W. R., S. P. Nishenko, L. R. Sykes, and J. Krause (1979). Seismic gaps and plate tectonics: seismic potential for major boundaries, Pageoph 117, 1082-1147.

McNally, K. C. and J. B. Minster (1981). Nonuniform seismic slip rates along the Middle America Trench, J. Geophys. Res. 86, 4949-4959.

Minster, J. B. and T. H. Jordan (1978). Present day plate motions, J. Geophys. Res. 83, 5331-5354.

Priestley, K. F. and T. G. Masters (1986). Source mechanism of the September 19, 1985 Michoacan earthquake and its implications, Geophys. Res. Letters 13, 601-604.

Reyes, A., J. N. Brune, and C. Lomnitz (1979). Source mechanism and aftershock study of the Colima, Mexico earthquake of January 30, 1973, Bull. Seism. Soc. Am. 69, 1819-1840.

Riedesel, M. A., T. H. Jordan, A. F. Sheehan, and P. G. Silver (1986). Moment-tensor spectra of the 19 Sept. 85 and 21 Sept. 85 Michoacan, Mexico, earthquakes, Geophys. Res. Letters 13, 609-612.

Silver, P. G. and T. H. Jordan (1983). Total-moment spectra of fourteen large earthquakes, J. Geophys. Res. 88, 3273-3293.

Singh, S. K., J. Yamamoto, J. Haskov, M. Guzmán, D. Novelo, and R. Castro (1980). Seismic gap of Michoacan, Mexico, Geophys. Res. Letters 7, 69-72.

Singh, S. K., L. Astiz, and J. Havskov (1981). Seismic gaps and recurrence periods of large earthquakes along the Mexican subduction zone: a reexamination, Bull. Seism. Soc. Am. 71, 827-843.

Singh, S. K., J. M. Espindola, J. Yamamoto, and J. Havskov (1982). Seismic potential of Acapulco-San Marcos region along the Mexican subduction zone, Geophys. Res. Letters 9, 633-636.

Singh, S. K., T. Dominguez, R. Castro, and M. Rodriguez (1984). $P$ waveform of large, shallow earthquakes along the Mexican subduction zone, Bull. Seism. Soc. Am. 74, 2135-2156.

Singh, S. K., L. Ponce, and S. P. Nishenko (1985). The great Jalisco, Mexico earthquakes of 1932: subduction of the Rivera plate, Bull. Seism. Soc. Am. 5, 1301-1314.

Stewart, G. S., E. P. Chael, and K. McNally (1981). The November 29, 1978, Oaxaca, Mexico earthquake. A large simple event, J. Geophys. Res. 86, 5053-5060.

Stolte, C., K. C. McNally, J. Gonzalez-Ruiz, G. W. Simila, A. Reyes, C. Rebollar, L. Munguia, and L. Mendoza (1986). Fine structure of a post-failure Wadati-Benioff zone, Geophys. Res. Letters 13, 577-580.

Tajima, F. (1984). Study of source processes of the 1965, 1968 and 1978 Oaxaca, earthquakes using shortperiod records, $J$. Geophys. Res. 89, 1867-1873.

Tajima, F. and K. McNally (1983). Seismic rupture patterns in Oaxaca, Mexico, J. Geophys. Res. 88, 4263-4276.

UNAM Seismology Group (1986). The September 1985 Michoacan earthquakes: aftershock distribution and history of rupture, Geophys. Res. Letters 13, 573-576. 
Valdés, C., R. P. Meyer, R. Zúñiga, J. Havskov, and S. K. Singh (1982). Analysis of the Petatán aftershocks: number, energy release and asperities, J. Geophys. Res. 87, 8519-8527.

Vogt, P. R., A. Lowrie, D. Bracey, and R. Hey (1976). Subduction of aseismic oceanic ridges: effects on shape, seismicity, and other characteristics of consuming plate boundaries, Geol. Soc. Am. Special Paper 172.

Wang, S., K. McNally, and R. J. Geller (1982). Seismic strain release along the Middle America trench, Mexico, Geophys. Res. Letters 9, 182-185.

Yamamoto, J. (1978). Rupture processes of some complex earthquakes in southern Mexico, Ph.D. Thesis, Saint Louis University, Missouri, $203 \mathrm{pp}$.

Zhang, J. and H. Kanamori (1987). Source finiteness of large earthquakes measured from long-period Rayleigh waves (submitted for publication).

SEISMOLOGICAL LABORATORY

California Institute of Technology

Pasadena, California 91125

Contribution No. 4412

Manuscript received 6 October 1986 